\title{
Peptide Bond Isosteres: Ester or $(E)$-Alkene in the Backbone of the Collagen Triple Helix
}

Cara L. Jenkins, Melissa M. Vasbinder, Scott J. Miller, and Ronald T. Raines*

Departments of Chemistry and Biochemistry, University of Wisconsin-Madison, Madison, Wisconsin 53706 and Department of Chemistry, Boston College,

Chestnut Hill, Massachusetts 02467

raines@biochem.wisc.edu

$\begin{array}{lll}\text { Page } & \text { Contents } \\ \text { S1 } & & \text { Table of Contents } \\ \text { S2-S4 } & & \text { Experimental Procedures } \\ \text { S5 } & & \text { Figure S1 } \\ \text { S6 } & & { }^{1} \mathrm{H} \text { NMR spectrum of } 3 \\ \text { S7 } & & { }^{1} \mathrm{H} \text { NMR spectrum of } 4 \\ \text { S8 } & & { }^{13} \mathrm{C} \text { NMR spectrum of } \mathbf{4} \\ \text { S9 } & & { }^{1} \mathrm{H} \text { NMR spectrum of } 5 \\ \text { S10 } & { }^{13} \mathrm{C} \text { NMR spectrum of } 5 \\ \text { S11 } & { }^{1} \mathrm{H} \text { NMR spectrum of } 6 \\ \text { S12 } & { }^{13} \mathrm{C} \text { NMR spectrum of } 6\end{array}$


General Experimental. Reagents were obtained from Aldrich Chemical or Fisher Scientific, and used without further purification. Amino acids and their derivatives were obtained from Fisher Scientific, Bachem Bioscience, or Novabiochem. Dichloromethane was distilled over $\mathrm{CaH}_{2}$ (s) or drawn from a Baker Cycletainer. Thin-layer chromatography was performed by using aluminum-backed plates coated with silica gel containing $F_{254}$ phosphor and visualized by UV illumination or staining with $\mathrm{I}_{2}, p$-anisaldehyde stain, or phosphomolybdic acid stain. Phosphatebuffered saline (PBS) contained (in $1.00 \mathrm{~L}) \mathrm{KCl}(0.20 \mathrm{~g}), \mathrm{KH}_{2} \mathrm{PO}_{4}(0.20 \mathrm{~g}), \mathrm{NaCl}(8.0 \mathrm{~g})$, and $\mathrm{Na}_{2} \mathrm{HPO}_{4} \cdot 7 \mathrm{H}_{2} \mathrm{O}(2.16 \mathrm{~g})$ at $\mathrm{pH} 7.4$.

NMR spectra were acquired with a Bruker AC+ 300 spectrometer $\left({ }^{1} \mathrm{H}: 300 \mathrm{MHz},{ }^{13} \mathrm{C}\right.$ : $75.4 \mathrm{MHz})$ or Varian UNITY-500 spectrometer $\left({ }^{1} \mathrm{H}: 500 \mathrm{MHz},{ }^{13} \mathrm{C}: 125.7 \mathrm{MHz}\right)$ at the University of Wisconsin-Madison Chemistry Instrument Center. Compounds with carbamate protecting group (e.g., Boc or Fmoc) exist as mixture of $Z$ and $E$ isomers that do not interconvert on the NMR time scale. Accordingly, these compounds exhibit two sets of NMR signals.

Mass spectrometry was performed with either a Micromass LCT (electrospray ionization, ESI) mass spectrometer in the University of Wisconsin-Madison Chemistry Instrument Center or with a Perkin-Elmer Voyager (matrix-assisted laser desorption ionization, MALDI) mass spectrometer in the University of Wisconsin-Madison Biophysics Instrumentation Facility.

Circular dichroism (CD) spectroscopy was performed with an Aviv 62A DS spectrometer in the University of Wisconsin-Madison Biophysics Instrumentation Facility.

(ProProGly) 10 was from Peptides International.

t-Butyloxycarbonyl-prolylglycine Benzyl Ester (3). $t$-Butyloxycarbonyl-proline (5.268 g, $24.5 \mathrm{mmol})$, glycine benzyl ester tosylate salt $(9.088 \mathrm{~g}, 26.9 \mathrm{mmol})$, dicyclohexylcarbodiimide (5.075 g, $24.5 \mathrm{mmol})$, and hydroxybenzotriazole hydrate $(3.756 \mathrm{~g}, 24.5 \mathrm{mmol})$ were dissolved in dry DMF $(200 \mathrm{~mL})$ and diisopropylethylamine $(12.8 \mathrm{~mL}, 73.5 \mathrm{mmol})$ was added. The reaction mixture was stirred overnight, filtered to remove DCU, and concentrated under reduced pressure. The residue was dissolved in EtOAc and washed twice each with aqueous $\mathrm{KHCO}_{3}(5 \% \mathrm{w} / \mathrm{v})$ and aqueous $\mathrm{KHSO}_{4}(5 \% \mathrm{w} / \mathrm{v})$ and once with brine. The organic layer was dried over $\mathrm{MgSO}_{4}(\mathrm{~s})$, filtered, and concentrated under reduced pressure. The crude product was purified by silica gel chromatography, eluting with 1:1 hexane/EtOAc to yield $3(6.987 \mathrm{~g}, 79 \%)$ as a white solid. ${ }^{1} \mathrm{H}$ NMR $\left(\mathrm{CDCl}_{3}, 300 \mathrm{MHz}\right) \delta: 7.39-7.28(\mathrm{~m}, 5 \mathrm{H}), 5.17(\mathrm{ABq}, J=12.3 \mathrm{~Hz}, 2 \mathrm{H}), 4.36-3.99(\mathrm{~m}, 3 \mathrm{H})$, $3.50-3.30(\mathrm{~m}, 2 \mathrm{H}), 2.36-1.82(\mathrm{~m}, 4 \mathrm{H}), 1.46(\mathrm{~s}, 9 \mathrm{H})$.

$\mathrm{N}$-(9H-Fluoren-9-ylmethoxycarbonyl)-prolylprolylglycine Benzyl Ester (4).

BocProGlyOBn (3, $4.259 \mathrm{~g}, 11.8 \mathrm{mmol})$ was dissolved in dioxane $(50 \mathrm{~mL})$ and placed under $\operatorname{Ar}(\mathrm{g})$ atmosphere. $4 \mathrm{~N} \mathrm{HCl}$ in dioxane $(29 \mathrm{~mL}, 116 \mathrm{mmol})$ was added with a syringe. The reaction mixture was stirred for $1.5 \mathrm{~h}$, and then concentrated to dryness. The residue was dissolved in dry DMF $(80 \mathrm{~mL})$, and diisopropylethylamine $(4.2 \mathrm{~mL}, 24.1 \mathrm{mmol})$ was added, followed by FmocPro pentafluorophenyl ester (5.934 g, $11.8 \mathrm{mmol})$. Additional DMF (20 mL) was added, then the reaction mixture was stirred overnight and then concentrated under reduced pressure. The crude product was purified by silica gel chromatography, eluting with EtOAc, to yield 4 (5.392 $\mathrm{g}, 79 \%)$ as a white solid. ${ }^{1} \mathrm{H} \mathrm{NMR}\left(\mathrm{CDCl}_{3}, 300 \mathrm{MHz}\right) \delta: 7.77-7.17(\mathrm{~m}, 13 \mathrm{H})$, 5.19-4.94 (m, 2H), 4.73-3.02 (m, 11H), 2.57-1.61 (m, 8H). ${ }^{13} \mathrm{C}$ NMR (125 MHz, DMSO- $d_{6}$, two rotamers) $\delta: 171.85,171.75,171.2,170.6,170.1,170.0,153.74,153.67,144.0,143.8,140.7$, $140.6,127.65,127.57,127.2,127.0,125.1,124.81,124.76,120.1,120.0,66.5,66.1,59.1,59.0$, 57.8, 57.3, 46.9, 46.6, 46.3, 46.1, 29.5, 28.91, 28.87, 28.6, 24.33, 24.26, 23.7, 22.6.

$\mathrm{N}$-(9H-Fluoren-9-ylmethoxycarbonyl)-prolylprolylglycine (5, FmocProProGly). Pd/C $(10 \% \mathrm{w} / \mathrm{w} \mathrm{Pd}, 0.372 \mathrm{~g})$ was added to solid 4 (3.692 g, $6.35 \mathrm{mmol})$ under an $\mathrm{Ar}(\mathrm{g})$ atmosphere. 
$\mathrm{MeOH}(100 \mathrm{~mL})$ was added and the flask was flushed well with $\operatorname{Ar}(\mathrm{g}) \cdot \mathrm{H}_{2}(\mathrm{~g})$ was added via a balloon, and the reaction mixture was stirred for $4.75 \mathrm{~h}$, filtered through Celite, and concentrated under reduced pressure. The resulting solid was triturated overnight with $\mathrm{EtOAc} / \mathrm{Et}_{2} \mathrm{O}$ and then filtered and air-dried to yield $5(2.7 \mathrm{~g}, 86 \%)$ as a white solid. ${ }^{1} \mathrm{H}$ NMR $\left(\mathrm{CD}_{3} \mathrm{OD}, 300 \mathrm{MHz}\right) \delta$ : 7.82-7.28 (m, 8H), 4.69-3.35 (m, 11H), 2.29-1.74 (m, 8H). ${ }^{13} \mathrm{C}$ NMR (125 MHz, DMSO- $d_{6}$, two rotamers): $\delta$ : 171.84, 171.76, 170.1, 170.0, 153.8, 153.7, 144.0, 143.8, 143.7, 140.7, 140.6, $127.64,127.57,127.1,127.0,125.1,124.81,124.76,120.1,120.0,66.5,66.0,59.2,59.0,57.8$, 57.3, 46.9, 46.6, 46.3, 46.1, 29.5, 28.91, 28.87, 28.6, 24.33, 24.26, 23.7, 22.6. ESI-HRMS: $m / z$ $490.1965\left([\mathrm{M}-\mathrm{H}]^{-}\right) ; 490.1978\left([\mathrm{M}-\mathrm{H}]^{-}\right.$, calcd $)$.

$\mathrm{N}$-(9H-Fluoren-9-ylmethoxycarbonyl)-prolylglycolate (6, FmocProOGly).

9-Fluorenylmethyloxycarbonylproline (FmocPro, $0.515 \mathrm{~g}, 1.53 \mathrm{mmol}$ ) and hydroxybenzotriazole $(0.275 \mathrm{~g}, 1.80 \mathrm{mmol})$ were dissolved in dry $\mathrm{CH}_{2} \mathrm{Cl}_{2}(25 \mathrm{~mL})$. Dicyclohexylcarbodiimide $(0.325 \mathrm{~g}, 1.58 \mathrm{mmol})$ was added, followed by benzyl glycolate $(0.25 \mathrm{~mL}, 1.76 \mathrm{mmol})$ and diisopropylethylamine $(0.55 \mathrm{~mL}, 3.16 \mathrm{mmol})$. The reaction mixture was stirred overnight, filtered to remove DCU, and concentrated under reduced pressure. The resulting yellow oil was dissolved in EtOAc, washed twice each with aqueous $\mathrm{KHCO}_{3}(5 \% \mathrm{w} / \mathrm{v})$ and aqueous $\mathrm{KHSO}_{4}$ $(5 \% \mathrm{w} / \mathrm{v})$, and then dried over $\mathrm{MgSO}_{4}(\mathrm{~s})$, filtered, and concentrated under reduced pressure. The crude product was purified by silica gel chromatography, eluting with 1:3 EtOAc/hexanes to yield the benzyl ester $(0.281 \mathrm{~g}, 38 \%)$ as a white foam. The benzyl ester (507 $\mathrm{mg}, 1.04 \mathrm{mmol})$ was combined with $\mathrm{Pd} / \mathrm{C}(10 \% \mathrm{w} / \mathrm{w} \mathrm{Pd}, 49 \mathrm{mg})$ under $\operatorname{Ar}(\mathrm{g})$, and to this solution was added $\mathrm{MeOH}(40 \mathrm{~mL})$. The flask was flushed with $\mathrm{Ar}(\mathrm{g})$, and $\mathrm{H}_{2}(\mathrm{~g})$ was introduced via a balloon. The reaction mixture was stirred for $3 \mathrm{~h}$, and then filtered through Celite and concentrated under reduced pressure. The crude product was purified by silica gel chromatography, eluting with $\mathrm{MeOH}(5-10 \% \mathrm{v} / \mathrm{v})$ in $\mathrm{CH}_{2} \mathrm{Cl}_{2}$ to yield $6(0.172 \mathrm{~g}, 42 \%)$ as a white solid. ${ }^{1} \mathrm{H} \mathrm{NMR} \mathrm{(300} \mathrm{MHz,}$ $\left.\mathrm{CDCl}_{3}\right) \delta: 9.12(\mathrm{bs}, 1 \mathrm{H}), 7.75-7.25(\mathrm{~m}, 8 \mathrm{H}), 4.73-4.14(\mathrm{~m}, 5 \mathrm{H}), 3.64-3.41(\mathrm{~m}, 2 \mathrm{H}), 2.27-1.81$ $(\mathrm{m}, 4 \mathrm{H}) .{ }^{13} \mathrm{C}$ NMR $\left(75 \mathrm{MHz}, \mathrm{CDCl}_{3}\right.$, two rotamers) $\delta: 171.7,170.7,170.6,155.2,154.7,143.9$, $143.8,143.6,143.5,141.2,127.6,127.0,125.0,124.9,124.8,124.7,119.9,67.7,67.4,60.7,60.5$, 58.9, 58.4, 47.0, 46.9, 46.5, 30.7, 29.7, 24.1, 23.1. ESI-HRMS: $m / z$ 394.1273 ([M - H] $]^{-}$; $394.1291\left([\mathrm{M}-\mathrm{H}]^{-}\right.$, calcd $)$.

$\mathbf{N}$-(9H-Fluoren-9-ylmethoxycarbonyl)-glycylproline (FmocGlyPro). Glycylproline (1.022 g, $5.94 \mathrm{mmol}$ ) was dissolved in aqueous $\mathrm{Na}_{2} \mathrm{CO}_{3}(10 \%(\mathrm{w} / \mathrm{v}), 20 \mathrm{~mL})$, and to this solution was added a solution of Fmoc- $\mathrm{Cl}(1.696 \mathrm{~g}, 6.56 \mathrm{mmol})$ in dioxane $(15 \mathrm{~mL})$. Additional dioxane $(30 \mathrm{~mL})$ was added, and the reaction mixture was stirred for $3 \mathrm{~h}$. Water $(100 \mathrm{~mL})$ was added, and the reaction mixture was washed twice with $\mathrm{Et}_{2} \mathrm{O}$. The aqueous layer was acidified to $\mathrm{pH} 2$ with $6 \mathrm{~N} \mathrm{HCl}$ and extracted four times with EtOAc. The combined EtOAc extracts were dried over $\mathrm{MgSO}_{4}(\mathrm{~s})$, filtered, concentrated under reduced pressure, and placed under high vacuum overnight to yield FmocGlyPro $(2.255 \mathrm{~g}, 96 \%)$ as a white solid. ${ }^{1} \mathrm{H} \mathrm{NMR}\left(300 \mathrm{MHz}, \mathrm{CDCl}_{3}\right) \delta$ : 9.84 (bs, 1H), 7.76-7.26 (m, 8H), 6.19, 5.93 (two broad m, 1H), 4.60-3.41 (m, 8H), 2.31-1.87 $(\mathrm{m}, 4 \mathrm{H}) .{ }^{13} \mathrm{C}$ NMR $\left(75 \mathrm{MHz}, \mathrm{CDCl}_{3}\right) \delta: 174.0,168.5,156.4,145.5,143.8,141.2,127.7,127.0$, $125.2,119.9,67.6,67.3,61.4,59.3,47.0,46.3,43.3,28.5,24.6$. ESI-MS: $m / z$ 393.1 ([M - H] $\left.]^{-}\right)$; $393.2\left([\mathrm{M}-\mathrm{H}]^{-}\right.$, calcd $)$.

Solid-Phase Peptide Synthesis. Peptides were assembled on solid phase using an Applied Biosystems Model 432A (Synergy) peptide synthesizer using HBTU with HOBt and DIEA as the coupling reagent, or an Applied Biosystems Pioneer instrument using HATU/DIEA as the coupling reagent. Both instruments employ the Fmoc/tBu coupling strategy. It was found that the best resin for collagen mimic peptide synthesis using the Synergy instrument was 2-chlorotrityl 
resin, and that the best resin for the Pioneer instrument was polyethyleneglycol-grafted polystyrene (PEG-PS) resin. Syntheses were carried out using 1.5-3.0 equiv of each segment to be coupled. Cleavage of the peptide from the resin was achieved by using 38:1:1 $\mathrm{TFA} / \mathrm{H}_{2} \mathrm{O} /$ triisopropyl silane (TIS) for $1.5-3.0 \mathrm{~h}$. Peptides were isolated by precipitation from the cleavage cocktail with $t$-butyl methyl ether, and purified by reverse-phase HPLC on a Varian Dynamax preparative C-18 column with a flow-rate of $4 \mathrm{~mL} / \mathrm{min}$ and elution with $15 \% \mathrm{v} / \mathrm{v}$ $\mathrm{CH}_{3} \mathrm{CN}$ in water (5 min), 15-50\% (30 min), 50-85\% (10 min), and 85\% (5 min). The purified peptides eluted after 35-40 min, and were analyzed by MALDI-TOF MS (Table S1).

Table S1. MALDI-TOF mass spectrometric analysis of depsipeptide 1 and alkenyl peptide 2.

\begin{tabular}{ccc}
\hline & \multicolumn{2}{c}{ MALDI-TOF MS } \\
\cline { 2 - 3 } Peptide & Observed $(\mathrm{M}+\mathrm{H})^{+}$ & Calculated $(\mathrm{M}+\mathrm{H})^{+}$ \\
\hline depsipeptide 1 & 2530.9 & 2531.3 \\
alkenyl peptide 2 & 2513.8 & 2513.3 \\
\hline
\end{tabular}

Circular Dichroism (CD) Spectroscopy of Depsipeptide 1. Depsipeptide $1(\sim 0.2 \mathrm{mM})$ was dissolved in $50 \mathrm{mM} \mathrm{AcOH}$ or in PBS containing TMAO $(0-4.0 \mathrm{M})$, and the resulting solutions were incubated at $4{ }^{\circ} \mathrm{C}$ for $\geq 24 \mathrm{~h}$. Solutions were degassed on ice under vacuum for approximately $20 \mathrm{~min}$ immediately before placement into pre-cooled $1-\mathrm{mm}$ pathlength quartz cuvettes. Wavelength spectra were recorded at $4{ }^{\circ} \mathrm{C}$ from $260-200 \mathrm{~nm}$, sampling every $1 \mathrm{~nm}$ and averaging for $3 \mathrm{~s}$ at each wavelength (Figure 1S, panel A). Temperature scans were conducted by raising the temperature of the samples in $3-{ }^{\circ} \mathrm{C}$ increments from $4{ }^{\circ} \mathrm{C}$ to $60-80{ }^{\circ} \mathrm{C}$ (depending on the $T_{\mathrm{m}}$ value of the triple helices being studied), equilibrating for $5 \mathrm{~min}$ at each temperature, and monitoring at $225 \mathrm{~nm}$ with a 20 -s averaging time for each data point. Wavelength spectra were recorded again at the highest temperature used in the temperature scans, using the same parameters as for the wavelength scan at $4{ }^{\circ} \mathrm{C}$. Values of $T_{\mathrm{m}}$ were determined by fitting the raw CD data (Figure 1S, panel B) using the software package NLREG 4.0 (Phillip Sherrod, 1998).

Circular Dichroism (CD) Spectroscopy of Alkenyl Peptide 2. Alkenyl peptide $\mathbf{2}$ was dissolved in $50 \mathrm{mM} \mathrm{AcOH}(0.36 \mathrm{mM})$ or in PBS $(0.22 \mathrm{mM})$ containing TMAO $(0-4.0 \mathrm{M})$, and the resulting solutions were incubated at $4{ }^{\circ} \mathrm{C}$ for $\geq 24 \mathrm{~h}$. Solutions were degassed under vacuum for $15 \mathrm{~min}$ at $0{ }^{\circ} \mathrm{C}$ immediately before placement into pre-cooled $1-\mathrm{mm}$ pathlength quartz cuvettes. Wavelength spectra were recorded at $4{ }^{\circ} \mathrm{C}$ from $200-260 \mathrm{~nm}$, sampling every $1 \mathrm{~nm}$ and averaging for $3 \mathrm{~s}$ at each wavelength (data not shown). Temperature scans were conducted by raising the temperature of the samples in $3-{ }^{\circ} \mathrm{C}$ increments from $4-73{ }^{\circ} \mathrm{C}$ and equilibrating for $10 \mathrm{~min}$ at each temperature and recording a spectrum from $210-260 \mathrm{~nm}$, sampling for $3 \mathrm{~s}$ every $3 \mathrm{~nm}$. Wavelength spectra were recorded again at $73{ }^{\circ} \mathrm{C}$, using the same parameters as for the wavelength scan at $4{ }^{\circ} \mathrm{C}$. Values of $T_{\mathrm{m}}$ were determined by fitting the raw $\mathrm{CD}$ data (Figure $1 \mathrm{~S}$, panel C) using the software package NLREG 4.0 (Phillip Sherrod, 1998 

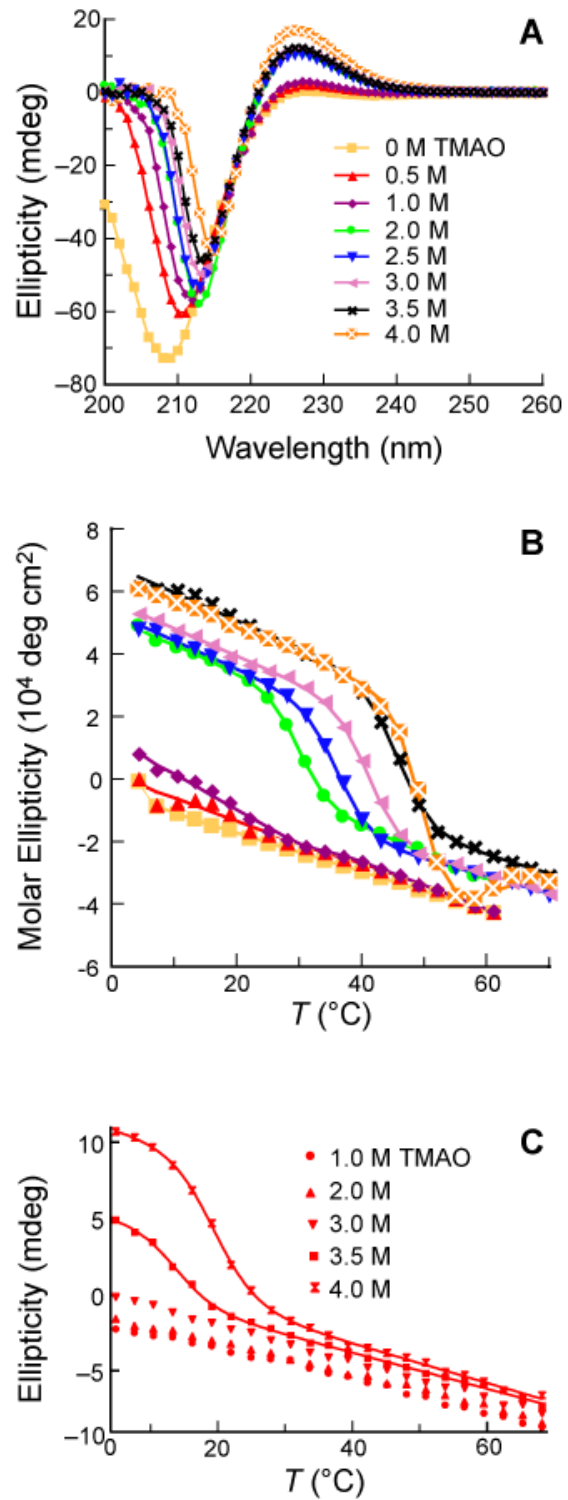

Figure S1. (A) Circular dichroism spectra of depsipeptide 1 at $4{ }^{\circ} \mathrm{C}$ in PBS containing trimethylamine $\mathrm{N}$-oxide $(0-4.0 \mathrm{M})$. (B) Molar ellipticity at $225 \mathrm{~nm}$ of depsipeptide 1 at $4-70{ }^{\circ} \mathrm{C}$ in PBS containing trimethylamine $\mathrm{N}$-oxide $(0-4.0 \mathrm{M})$. (C) Ellipticity at $225 \mathrm{~nm}$ of alkenyl peptide 2 at $4-70{ }^{\circ} \mathrm{C}$ in PBS containing trimethylamine $\mathrm{N}$-oxide $(1.0-4.0 \mathrm{M})$. 


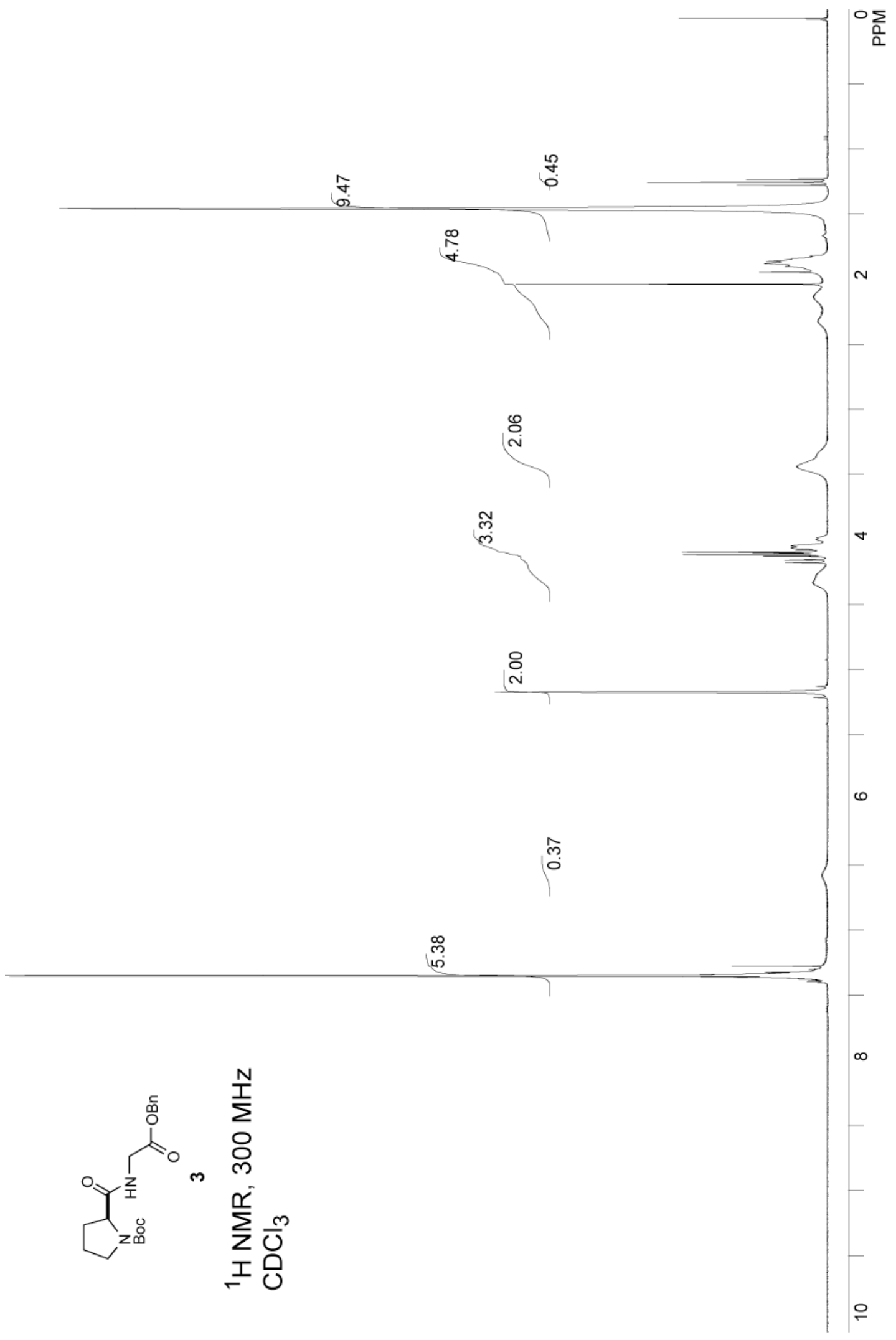




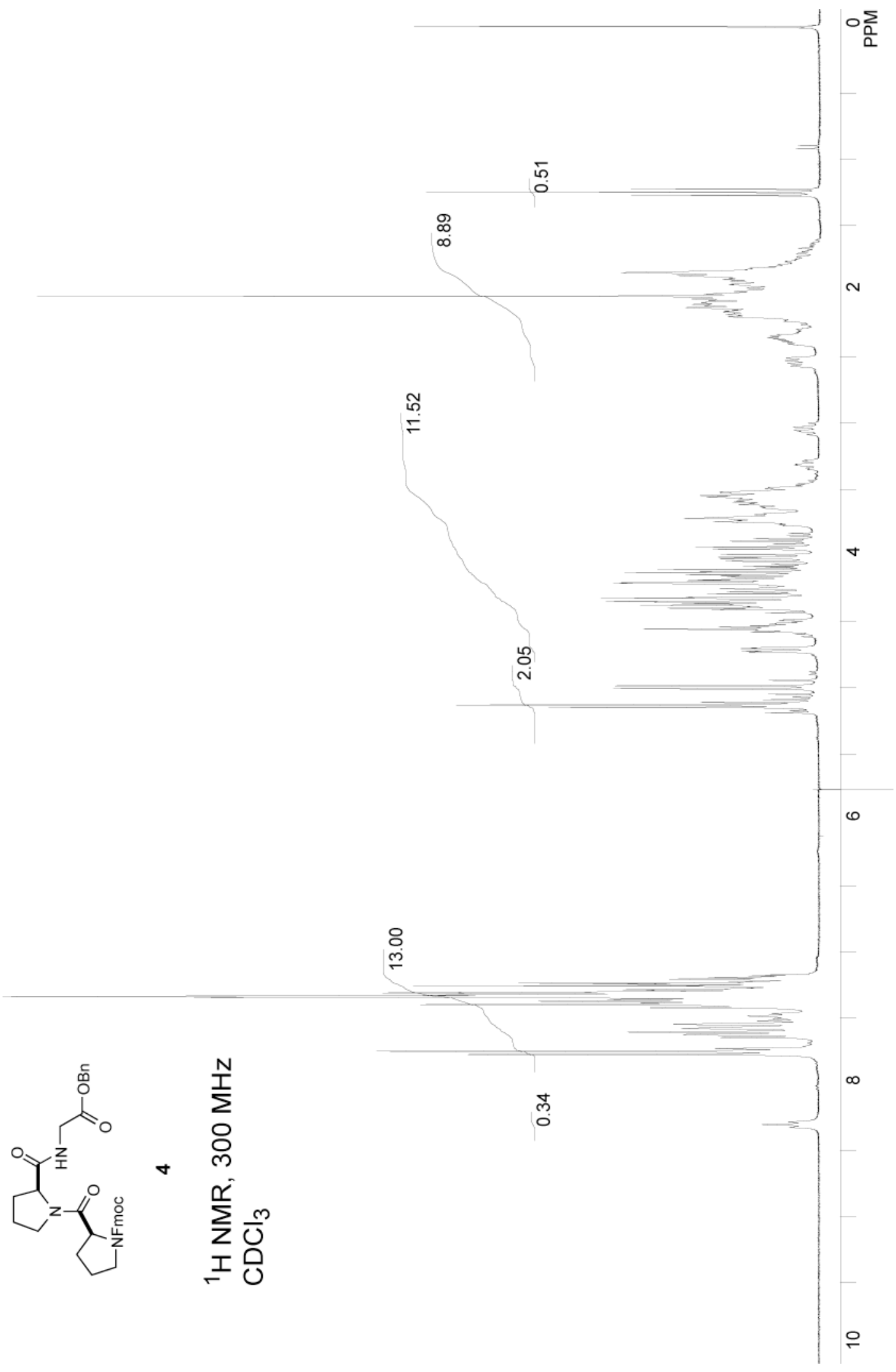




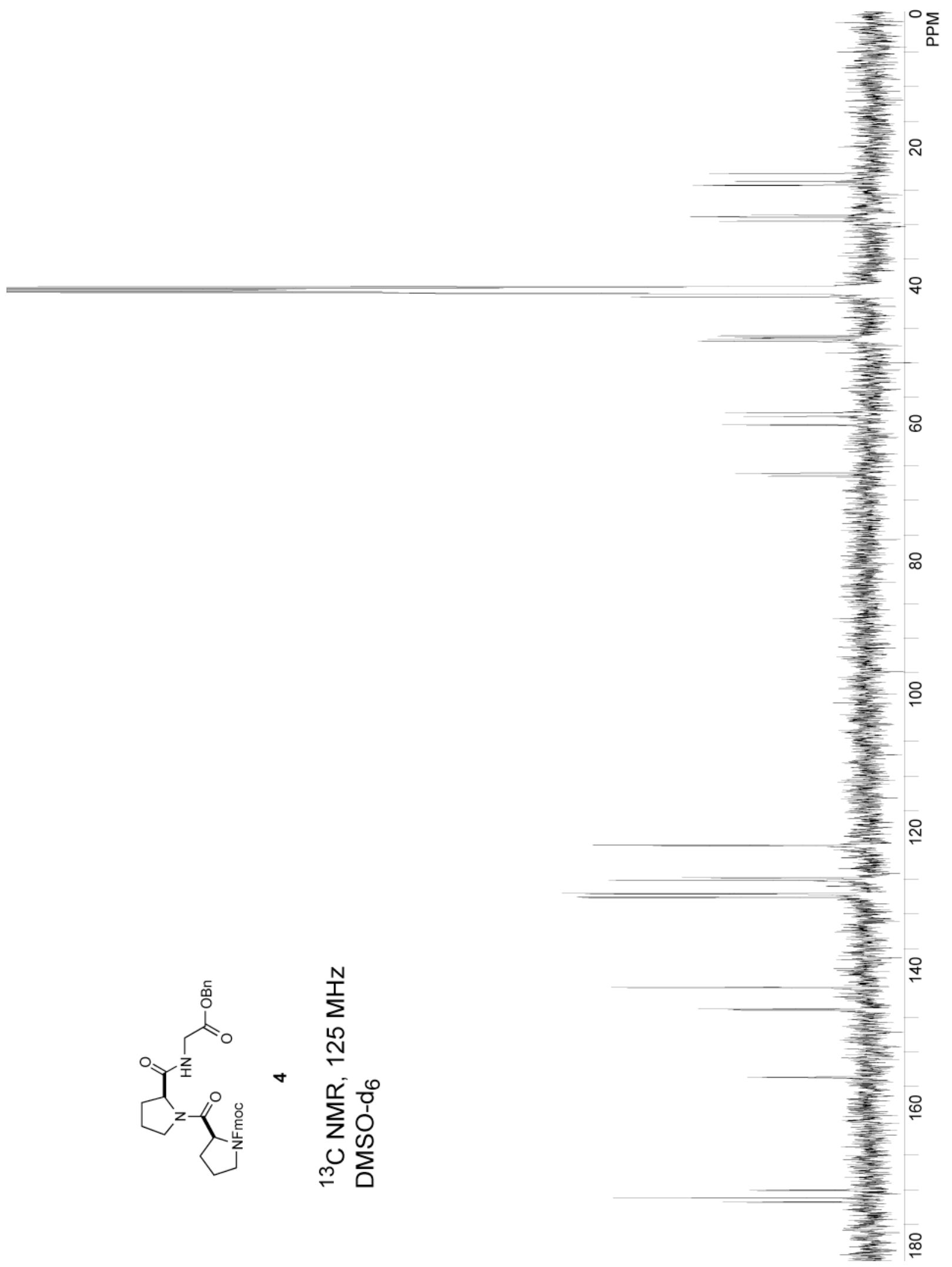




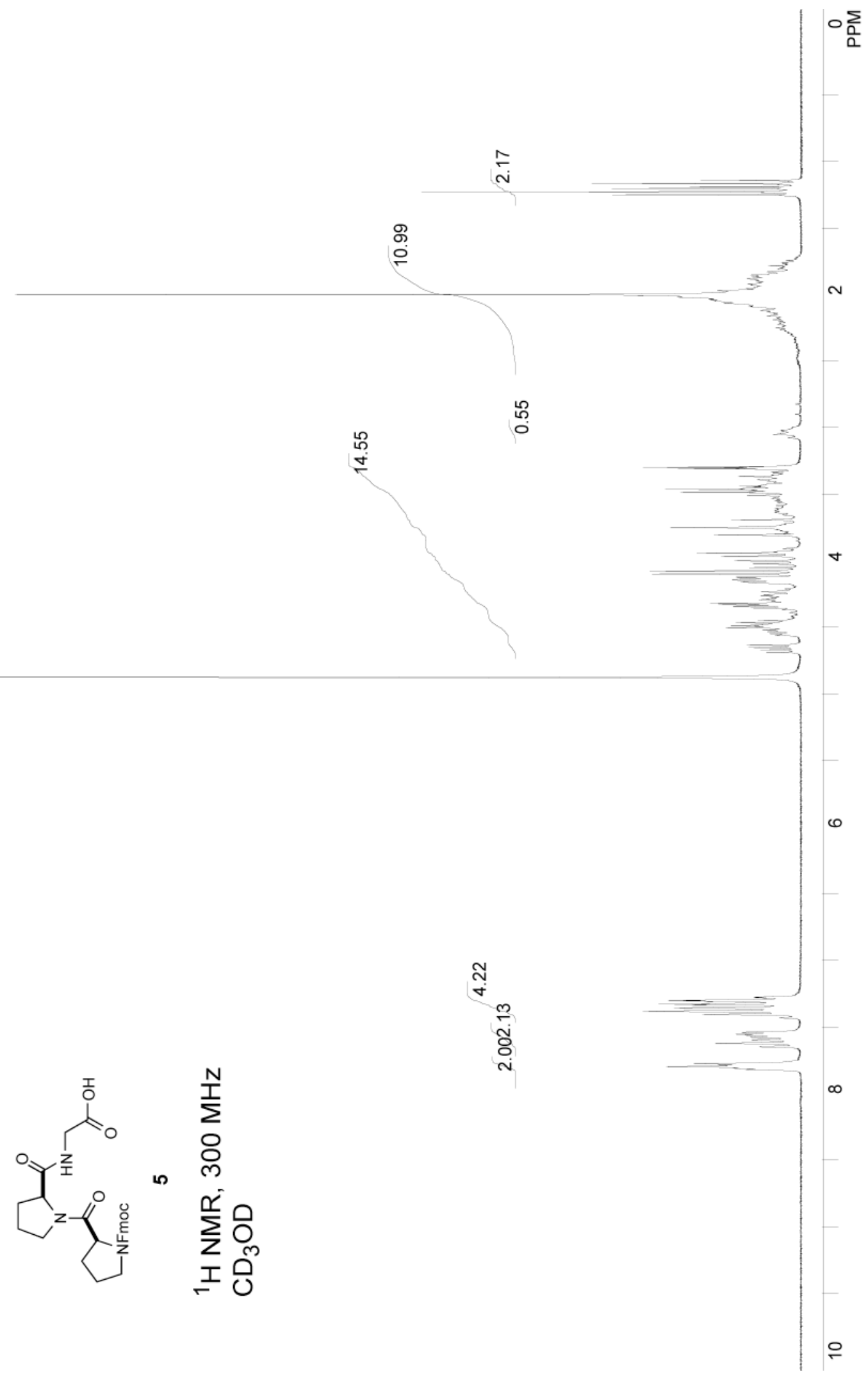




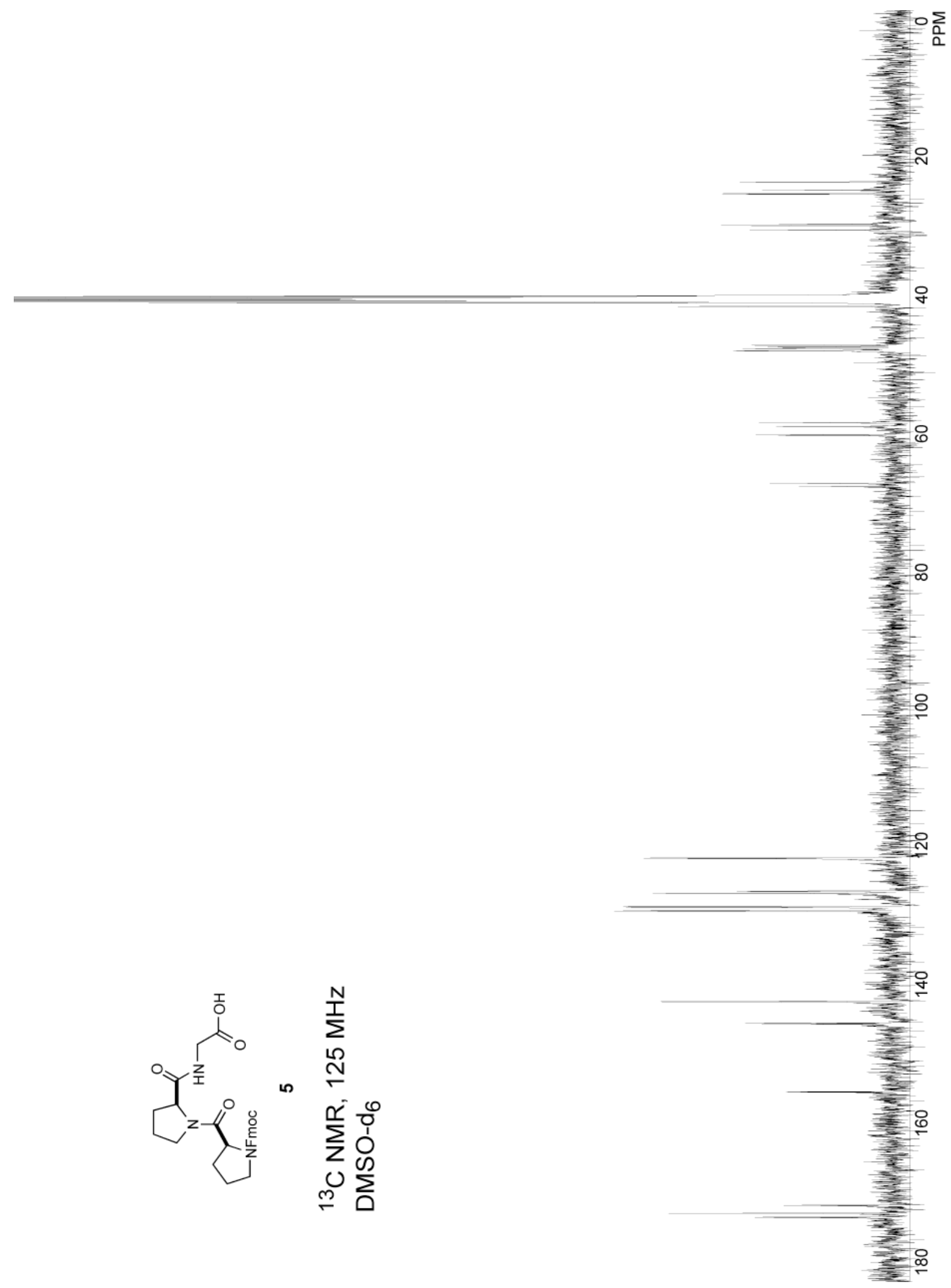




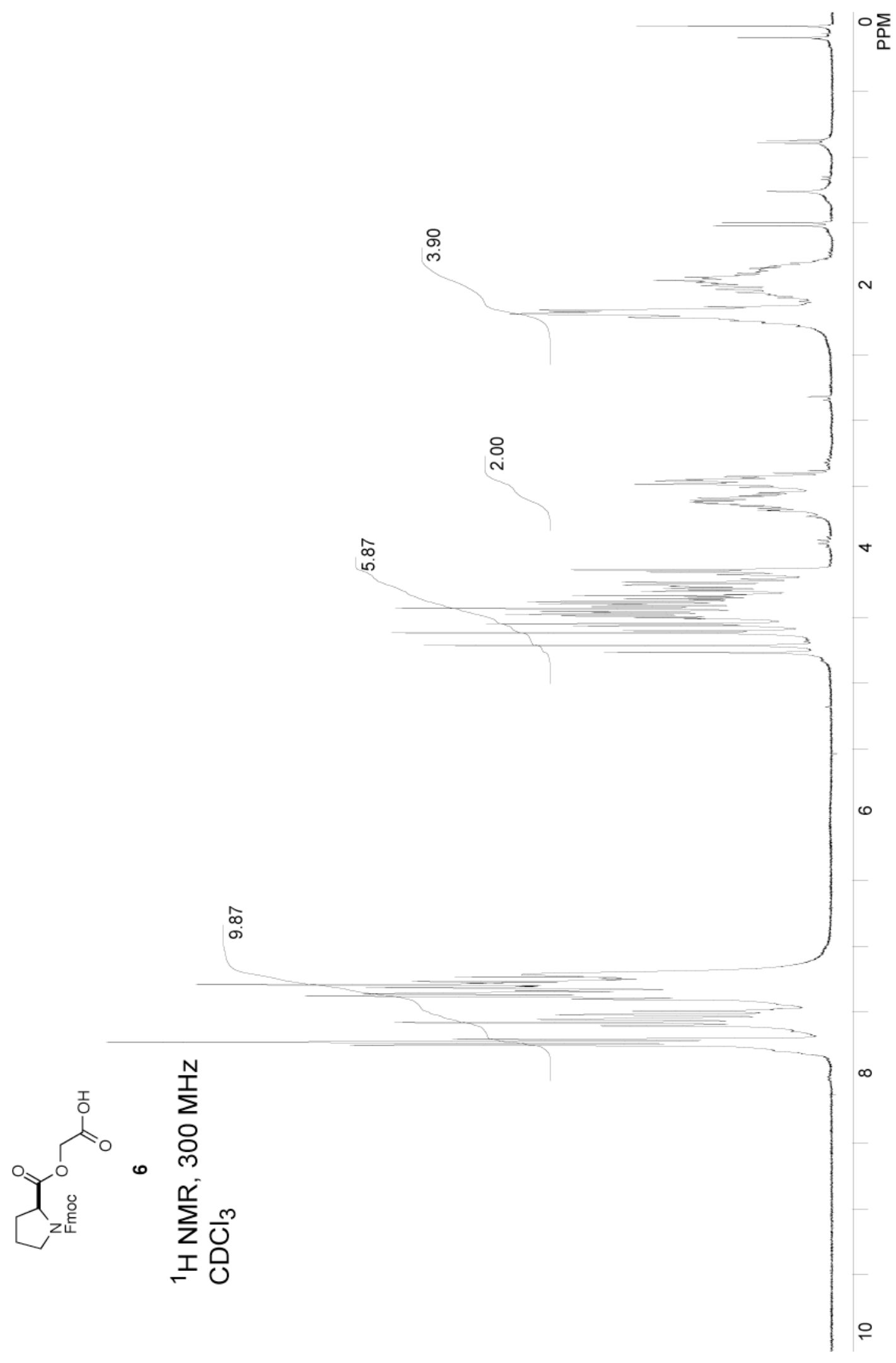




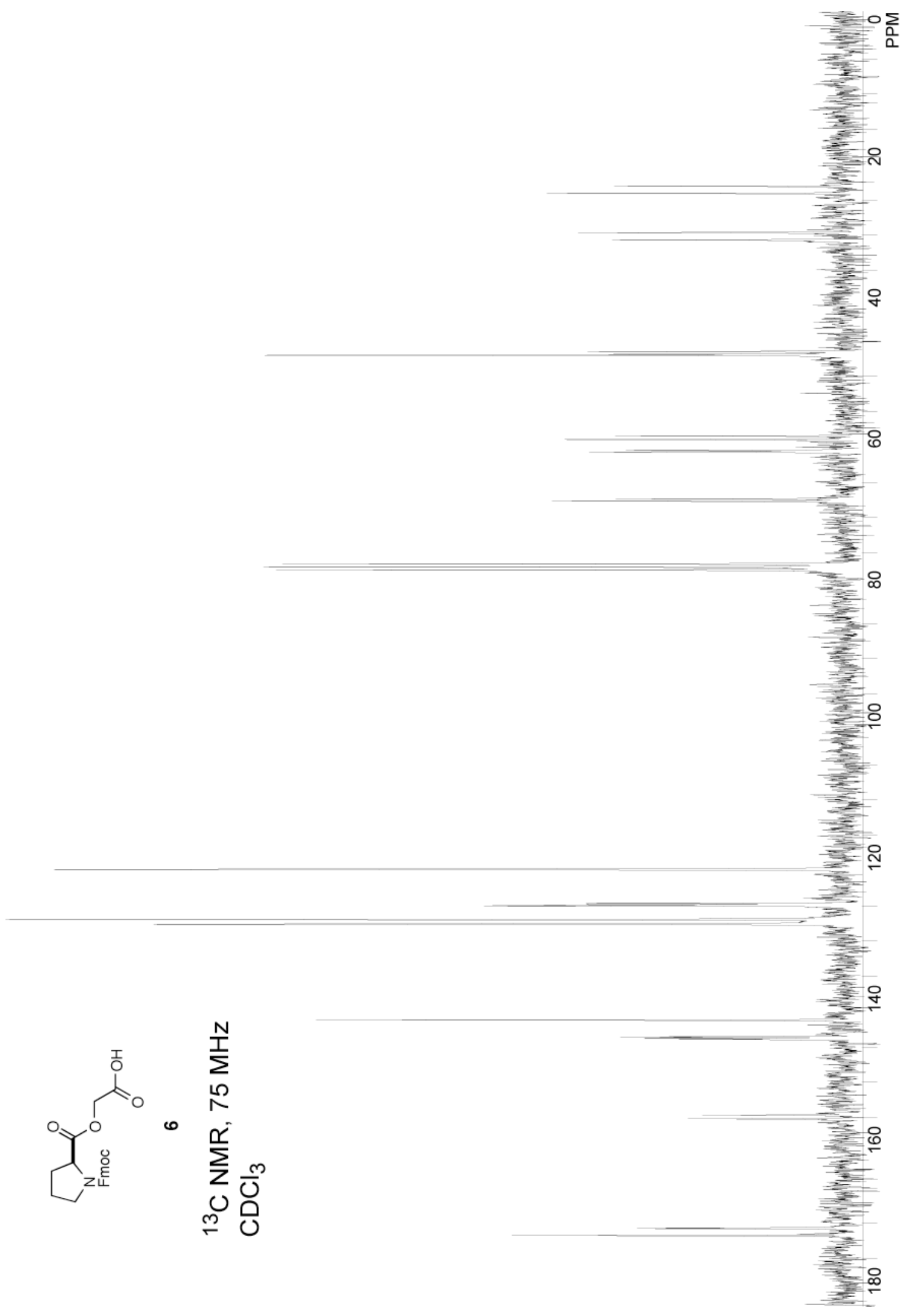

